\title{
INSECTICIDAL ACTIVITY OF EUCALYPTUS SP. VOLATILE OIL AGAINST BACKSWIMMER INSECT ANISOPS SARDEA
}

\author{
H. B. Ali ${ }^{1}$ \\ I. J. Abed ${ }^{1}$ \\ R. S. Augul ${ }^{2}$ \\ H. Y. Fadhil ${ }^{1}$ \\ Assist. Prof. \\ Assist. Prof. \\ Prof. \\ Assist. Prof. \\ ${ }^{1}$ Dept. Biol. Coll. Sci. University of Baghdad. \\ ${ }^{2}$ Dept. Entom. Invert, Iraq Natural History Research \\ Center and Museum, University of Baghdad \\ hayder.ali1130@yahoo.com
}

\section{ABSTRACT}

The objective of this study was to evaluate a natural bio-insecticide manufacturing from Eucalyptus sp. volatile oil. The use of Eucalyptus sp. against the Backswimmer insect Anisops sardea Herrich-Schaeffer, 1849 predatory of larvae of common carp fish, Cyprinus carpio L., in artificial closed ponds in Babylon province represented a new idea in Iraq. The volatile oil of the Eucalyptus sp. was extracted by hot water method using the Clevenger, three concentrations of 250000,450000 and $650000 \mathrm{ppm}$ with benzyl benzoate as a stabilizer were used, which has a boiling point of $324^{\circ} \mathrm{C}$ (slow evaporation) at field experiment.The results of field and laboratory experiments of the extracted volatile oil in different concentrations, showed that the lower concentration used, the longer exposure time should be, the lowest experimental concentration (250000) ppm was effective for killing half the number of LC50 insects in the field after 30 minutes, with less concentration LC50 killer for laboratory insects 20 minutes after exposure. While the killing rate did not exceed $2.7 \%$ at laboratory experiment and $1.5 \%$ at field experiment with regard to the effect of the volatile oil on fish larvae was at all times and for different experimental concentrations. A gas chromatography detection of the active compounds that found in the volatile oil of Eucalyptus was performed. The results showed that it contained the following compounds: sabinen $(0.06 \%)$, terpinen $(2 \%)$, camphenin $(3.4 \%)$, lemonine $(1.08 \%)$, myrcine $(0.62 \%)$, alph-pinene $(10 \%)$, linalool (0.027\%), camphor $(6.9 \%)$.

Keywords: Eucalyptus sp , A. sardea. Cyprinus carpio, natural insecticide

علي وآخرون

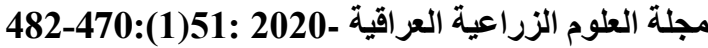

الفعالية القاتلة للحشرات للزيت الطيار لليوكالبتوز Eucalyptus sp ضد حشرة سابحات الظهر

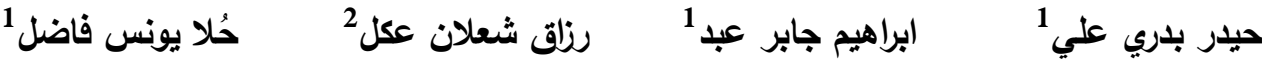

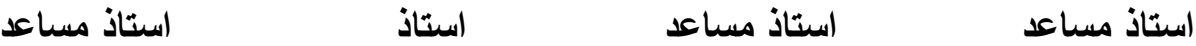

$$
\begin{aligned}
& \text { 1- قسم علوم الحياة- كلية العلوم، جامعة بغداد، العرلق }
\end{aligned}
$$

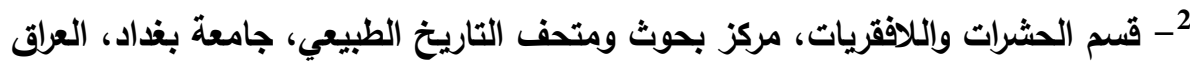

المستخلص

تهلف الرسالة الى تقييم مبيد حيوي طبيعي مصنع من الزيت الطيار المستخلص من اولق اشجار اليوكالبتوز. تعد استخام الزيوت الطيارة لاولق اليوكالبتوز ضد سابحلت الظهر Anisops sardea Herrich-Schaeffer, 1849 ، المفترسة ليرقات اسماك الكارب الثائعة. Cyprinus carpio L في الأحواض المغلقة الاصطناعية لتربية الاسماك فكرة جديدة في العرلق والتي استخدمت في محافظة بابل. استخلص الزيت الطيار من اولق اليوكالبتوزيواسطة طريقة التقطيربالماء الحار باستخدام Clevenger ، تم استخدام ثلاثة تراكيز من مستخلص اليوكالبتوز 250000 و 250000 و 650000 جزء في المليون مع بنزل البنزوات كمثبت، والذي يحتوي على نقطة غليان تبلغ 324 درجة مئوية (ذو تبخر بطيء) في التجربة الميدانية. أظهرت نتائج التجارب الحقلية والمختبرية لمستخلص فئون الزيت الطيار

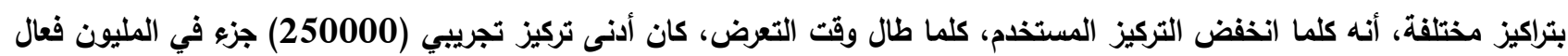
في قتل نصف عدد LC50 الحشرات في الحقل بعد 30 دقيقة ،مع اقل تركيز، قاتل LC50 للحشرات في المختبر بعد 20 دقيقة من التعرض.في حين أن معدل القتل لم يتجاوز 2.7 ٪ في المختبر و 1.5 ٪ في الحقل فيما يتعلق بتأثير الزيت الطيار على يرقات الأسماك

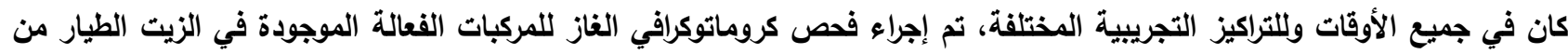

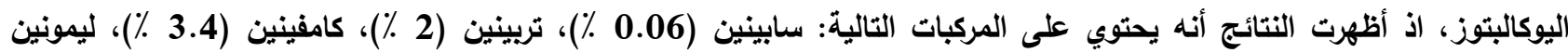

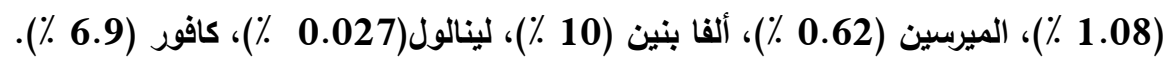

الكلمات المفتاحية: زيت لليوكالبتوز، الحشرة المفترسة Anisops sardea . . اسماك الكارب Cyprinus carpio مبيد طبيعي

\footnotetext{
*Received:23/7/2019, Accepted:2/10/2019
} 


\section{INTRODUCTION}

Anisops sardea Herrich-Schaeffer 1849

(Hemiptera: Notonectidae) subfamily

Anisopinae (33), is a small-bodied aquatic backswimmer found in high densities in many temporary pools and permanent water bodies throughout India, Which is found in high densities in late-season temporary pools (23, 31 ), as well as in permanent pools, this species usually live in temporal and permanent fresh, brackish and salt water ponds, lakes and coils with aquatic vegetation (4). Members of Notonectidae (Backswimmers) are very aggressive predators, attacking many pelagic and benthic invertebrates, including their own immature stages, invertebrates that fall onto the water surface (larvae and adults of various insects, mites, small crustaceans, annelids, and mollusks), and small vertebrates (fish larvae and amphibian tadpoles) $(13,19)$. In general, the genus Anisops Spinola, 1837 lives in permanent and brackish freshwater ponds, lakes and springs with aquatic plants; although they are primarily aquatic, they can fly well and thus can be easily transmitted to new habitats or other aquatic environments $(9,26$, 31) and being predators can be a good species in the biological control of mosquitoes. Laboratory based predatory experiments have exposed that $A$. sardea have a high predation rate on larval Culex mosquitoes $(41,43)$. The species can be distinguished by a shorter, slender, and laterally slightly depressed body with total size $(7.2-8.4 \mathrm{~mm})(8,21,40)$. A. sardea has a wide distribution range including Africa (tropical region, Algeria, Egypt, Libya, Morocco, Tunisia), Asia (Armenia, Azerbaijan, Georgia, India, Iran, Iraq, Israel, Jordan, Lebanon, Myanmar, Saudi Arabia, Syria, Turkey, Turkmenistan, United Arab Emirates, Yemen) and Europe (Albania, Bosnia and Herzegovina, Bulgaria, Croatia, Cyprus, France (Corsica), Greek, Italy (incl. Sicily and Sardinia), Malta, Portugal, Spain, Slovakia, Southern Russia) (3, 10,11, 17, 18, 20, 22, 28, 33,34, 39). Plant materials with pesticide properties have traditionally been used around the world without the emergence of resistant species, plant pesticides, when compared with industrial pesticides, are safer for the environment and are generally less expensive and easy to manufacture and use
$(38,14)$, so the need to use essential oils (volatile oils) was an alternative to control many field and house insects pests $(35,36$, 37). Volatile oils are aromatic volatile hydrocarbons that give a pungent flavor to the plant and are produced through the secondary metabolic pathways of the plant. Volatile oils have many important functions of the plant, including, protecting the plant tissues from freezing and heat effect, attract or expel insects and use them as a defense against predators and against fungal infections, most essential oils have also been used as flavorings, food additives, perfume ingredients, cosmetics, plastic products and soap. Several studies have shown that the volatile oils, including the volatile oil of Eucalyptus sp. have a wide range of effect against insect pests and fungal plant pathogens ranging from insect killer, attractant, repellent, egg laying hindrance and against growth regulator activities $(18,30)$. The aim of this study was to evaluate the activity of volatile oil of Eucalyptus sp. as natural friendly bio-insecticide against $A$. sardea predators of larvae of common carp fish, Cyprinus carpio L., which cause losses according to field observations about (70-90) $\%$ of the production of these larvae in artificial fish ponds in closed ponds in Babylon province

\section{MATERIALS AND METHODS}

1- Preparation of fish larvae for transfer to the artificial pond: A muddy aquarium was selected from artificial fish pond in Babylon province / Al-Musayyib district with an area of $3 * 6$ meters for the purpose of performing field experiment with preparing larvae of fish (3-4 days old) for transfer from larval incubators to fish pond in the morning.

2- Preparation of Eucalyptus leaves used in the experiment: The leaves of Eucalyptus sp. were obtained from trees surrounding the artificial fish pond in Musayyib district, the leaves were collected and cleaned from dust and then dried at room temperature, then crushed as a fine particles and preserved until use, the diagnosis was confirmed by the Herbarium of the College of Science / University of Baghdad.

3 - Preparation and extraction of volatile oil: Volatile oils were extracted using the hot water distillation method by Clevenger (1), and then collects the condensed liquid and 
separates the oil from the water using a separation funnel, the extracted oil was stored in special sealed bottles at $4{ }^{\circ} \mathrm{C}$.

4- Preparation of the extracted volatile oil: The insecticide was prepared by mixing the volatile oil of Eucalyptus leaves in different concentrations 250, 450 and $650 \mathrm{ppm}$ of Benzyl benzoate stabilizer, which characterized as boiling temperature of $324^{\circ}$ C (slow evaporation) that act as a suitable stabilizer for volatile oil when used in the field experiment.

5- Collection and diagnose the insect: Anisops sardea was collected and diagnosed by the Iraq Natural History Research Center and Museum / University of Baghdad; the insects were reared using water breeding ponds with a diameter of $50 * 100 \mathrm{~cm}$.

6- Laboratory control: Insects were collected from breeding ponds and placed in experimental ponds; the insects were divided into six groups and each group into three replicates of 40 insects per repeater with about 350 of breeding fish larvae, Each group was sprayed with $2 \mathrm{ml}$ for each of the above- mentioned concentrations at a height of 30-40 $\mathrm{cm}$ with a fine plastic sprayer used to spray cleaning fluids (2), the experimental ponds were provided with a flowing source of water in order to maintain a constant temperature (15 $\pm 2)^{\circ} \mathrm{C}$ throughout the experiment period. Percentage of mortality per insects and breeding fish larvae was calculated after: 5, 10, 15, 20, 25 and 30 minutes after treatment.

7- Field control: The experiment was carried out in the field on 11-7-2018 in a muddy aquarium in the artificial fish pond with an area $3 * 6$ meters in Babylon province / Musayyib district, after the experiment pond was sprayed with a volume of $200 \mathrm{ml}$ of concentration 250,000;450,000 and 650,000 ppm, three replicates of this treatment were taken from the water of the experimental pond. Adults of insect and breeding fish larvae were calculated randomly for each experimental replicates separately, the mortality rate was calculated before spraying and after 10, 15, 20, 25 and 30 minutes after treatment using Abbott's formula:

\section{Corrected $\%=\left(1-\frac{n \text { in } \mathbf{T} \text { after treatment }}{n \text { in Co after treatment }}\right) * 100$}

Where: $\mathbf{n}=$ Insect population, $\mathbf{T}=$ treated, $\mathbf{C o}=$ control 8- Gas Chromatography: Gas chromatography was used to detect the active compounds in the model; standard compounds were used imported from Supelco Company USA, the prepared standard material was injected at a known concentration of the device and according to the method of work established by the manufacturer to determine the identity of each compound based on the time of retention. The sample was then injected to determine the types of compounds in which it was diagnosed in that sample based on the time of retention and compare the time of retention of standard compounds with the time of retention of peaks that appeared in the model. To determine its concentration, the area under the curve was compared with the area under the curve in the standard compound according to the equation:

Sample Concentration

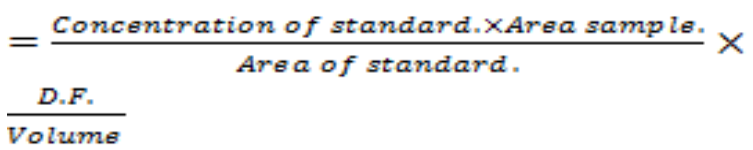

9- Statistical Analysis: The results were analyzed using SPSS (V.25) Probit Regression Analysis to calculate the lethal concentration of half of the experimental number as well as to calculate the frequency and percentages over different time periods and plot the regression curves to extract the correlation coefficient (R2).

\section{RESULTS AND DISCUSSION}

In Tables (1-4) two factors were changed concentration of essential oil and exposure time, that the bioactivity of the Eucalyptus essential volatile oil depends upon several factors such as (type and nature of the constituents and their individual concentration. Moreover varies with species, season, location, climate, soil type, age of the leaves, fertility regime, the method used for drying the plant material, and method of oil extraction $(6,9)$. 
Table 1. Effect of volatile oil of Eucalyptus sp. In concentrations 450,000 and $650,000 \mathrm{ppm}$ on adults of Anisops sardeus in laboratory experiment

\begin{tabular}{|c|c|c|c|c|c|c|c|}
\hline \multicolumn{2}{|c|}{ Number / } & Con. & $\begin{array}{c}\text { Number of } \\
\text { insects }\end{array}$ & $\begin{array}{c}\text { Observed } \\
\text { Responses }\end{array}$ & $\begin{array}{l}\text { Expected } \\
\text { Responses }\end{array}$ & Residual & $\begin{array}{c}\text { Probabilit } \\
\text { y \% }\end{array}$ \\
\hline PROBI & 1 & 250.000 & 40 & 7 & 6.686 & .314 & 16.7 \\
\hline T After & 2 & 450.000 & 40 & 7 & 7.640 & $-.640-$ & 19.1 \\
\hline $5 \mathrm{~min}$ & 3 & 650.000 & 40 & 9 & 8.674 & .326 & 21.7 \\
\hline PROBI & 1 & 250.000 & 40 & 12 & 12.005 & $-.005-$ & 30 \\
\hline T After & 2 & 450.000 & 40 & 13 & 12.989 & .011 & 32.5 \\
\hline $10 \mathrm{~min}$ & 3 & 650.000 & 40 & 14 & 14.005 & $-.005-$ & 35 \\
\hline PROBI & 1 & 250.000 & 40 & 16 & 16.666 & $-.666-$ & 41.7 \\
\hline T After & 2 & 450.000 & 40 & 21 & 19.660 & 1.340 & 49.2 \\
\hline $15 \mathrm{~min}$ & 3 & 650.000 & 40 & 22 & 22.667 & $-.667-$ & 56.7 \\
\hline PROBI & 1 & 250.000 & 40 & 26 & 26.293 & $-.293-$ & 65.7 \\
\hline T After & 2 & 450.000 & 40 & 32 & 31.448 & .552 & 78.6 \\
\hline $20 \mathrm{~min}$ & 3 & 650.000 & 40 & 35 & 35.252 & $-.252-$ & 88.1 \\
\hline PROBI & 1 & 250.000 & 40 & 37 & 36.972 & .028 & 92.4 \\
\hline T After & 2 & 450.000 & 40 & 40 & 39.990 & .010 & 100 \\
\hline $25 \mathrm{~min}$ & 3 & 650.000 & 40 & 40 & 40.000 & .000 & 100 \\
\hline PROBIT & 1 & 250.000 & 40 & 40 & 40.000 & .000 & 100 \\
\hline After 30 & 2 & 450.000 & 40 & 40 & 40.000 & .000 & 100 \\
\hline $\min$ & 3 & 650.000 & 40 & 40 & 40.000 & .000 & 100 \\
\hline
\end{tabular}

Table 2. Effect of pilot oil for Eucalyptus sp. in concentrations (250,000, 450,000 and $650,000 \mathrm{ppm}$ on breeding carp fish larvae in laboratory experiment

\begin{tabular}{|c|c|c|c|c|c|c|c|}
\hline Number & & con & $\begin{array}{l}\text { Number of } \\
\text { fish larvae }\end{array}$ & $\begin{array}{l}\text { Observed } \\
\text { Responses }\end{array}$ & $\begin{array}{l}\text { Expected } \\
\text { Responses }\end{array}$ & $\begin{array}{c}\text { Residua } \\
\quad 1\end{array}$ & $\begin{array}{c}\text { Probabili } \\
\text { ty \% }\end{array}$ \\
\hline PROBIT & 1 & 250.000 & 650 & 5 & 5.081 & -.081- & 0.8 \\
\hline \multirow[t]{2}{*}{ After 5 min } & 2 & 450.000 & 650 & 7 & 6.832 & .168 & 1.1 \\
\hline & 3 & 650.000 & 650 & 9 & 9.087 & $-.087-$ & 1.4 \\
\hline PROBIT & 1 & 250.000 & 650 & 7 & 6.932 & .068 & 1.1 \\
\hline After 10 & 2 & 450.000 & 650 & 9 & 9.140 & $-.140-$ & 1.4 \\
\hline $\min$ & 3 & 650.000 & 650 & 12 & 11.928 & .072 & 1.8 \\
\hline PROBIT & 1 & 250.000 & 650 & 10 & 9.263 & .737 & 1.4 \\
\hline After 15 & 2 & 450.000 & 650 & 10 & 11.516 & $-1.516-$ & 1.8 \\
\hline $\min$ & 3 & 650.000 & 650 & 15 & 14.221 & .779 & 2.2 \\
\hline PROBIT & 1 & 250.000 & 650 & 10 & 9.454 & .546 & 1.5 \\
\hline After 20 & 2 & 450.000 & 650 & 11 & 12.127 & $-1.127-$ & 1.9 \\
\hline $\min$ & 3 & 650.000 & 650 & 16 & 15.418 & .582 & 2.4 \\
\hline PROBIT & 1 & 250.000 & 650 & 12 & 11.249 & .751 & 1.7 \\
\hline After 25 & 2 & 450.000 & 650 & 12 & 13.539 & -1.539 & 2.1 \\
\hline $\min$ & 3 & 650.000 & 650 & 17 & 16.212 & .788 & 2.5 \\
\hline PROBIT & 1 & 250.000 & 650 & 12 & 12.222 & $-.222-$ & 1.9 \\
\hline After 30 & 2 & 450.000 & 650 & 15 & 14.546 & .454 & 2.2 \\
\hline $\min$ & 3 & 650.000 & 650 & 17 & 17.232 & $-.232-$ & 2.7 \\
\hline
\end{tabular}


Table 3. Effect of volatile oil of Eucalyptus sp. In concentrations 450,000 and $650,000 \mathrm{ppm}$ on adults of Anisops sardeus in field experiment

\begin{tabular}{|c|c|c|c|c|c|c|c|}
\hline \multicolumn{2}{|c|}{ Number / } & Con & Number of & Observed & Expected & Residual & Probabilit \\
\hline PROBI & 1 & 250.000 & 40 & 5 & 4.695 & .305 & 11.7 \\
\hline T After & 2 & 450.000 & 40 & 5 & 5.627 & $-.627-$ & 14.1 \\
\hline $5 \mathrm{~min}$ & 3 & 650.000 & 40 & 7 & 6.678 & .322 & 16.7 \\
\hline PROBI & 1 & 250.000 & 40 & 9 & 9.009 & -.009 & 22.5 \\
\hline T After & 2 & 450.000 & 40 & 10 & 9.982 & .018 & 25 \\
\hline $10 \mathrm{~min}$ & 3 & 650.000 & 40 & 11 & 11.009 & $-.009-$ & 27.5 \\
\hline PROBI & 1 & 250.000 & 40 & 13 & 14.005 & -1.005 & 35 \\
\hline T After & 2 & 450.000 & 40 & 16 & 16.960 & 2.040 & 42.4 \\
\hline $15 \min$ & 3 & 650.000 & 40 & 19 & 20.025 & $-1.025-$ & 49.1 \\
\hline PROBI & 1 & 250.000 & 40 & 15 & 15.670 & $-.670-$ & 39.2 \\
\hline T After & 2 & 450.000 & 40 & 20 & 18.648 & 1.352 & 46.6 \\
\hline $20 \min$ & 3 & 650.000 & 40 & 21 & 21.675 & $-.675-$ & 54.2 \\
\hline PROBI & 1 & 250.000 & 40 & 17 & 17.831 & -.831- & 44.6 \\
\hline T After & 2 & 450.000 & 40 & 22 & 20.334 & 1.666 & 50.8 \\
\hline $25 \min$ & 3 & 650.000 & 40 & 22 & 22.829 & $-.829-$ & 57.1 \\
\hline PROBI & 1 & 250.000 & 40 & 19 & 19.988 & $-.988-$ & $\approx 50$ \\
\hline T After & 2 & 450.000 & 40 & 25 & 23.033 & 1.967 & 57.6 \\
\hline $30 \mathrm{~min}$ & 3 & 650.000 & 40 & 25 & 25.969 & -.969 - & 64.9 \\
\hline
\end{tabular}

Table 4. Effect of volatile oil for Eucalyptus sp. In concentrations $\mathbf{( 2 5 0 , 0 0 0 ,}$ 450,000 and $650,000 \mathrm{ppm}$ on breeding carp fish larvae in field experiment

\begin{tabular}{|c|c|c|c|c|c|c|c|}
\hline \multicolumn{2}{|c|}{ Number / } & con & $\begin{array}{l}\text { Number of } \\
\text { fish larvae }\end{array}$ & $\begin{array}{l}\text { Observed } \\
\text { Responses }\end{array}$ & $\begin{array}{c}\text { Expected } \\
\text { Responses }\end{array}$ & Residual & $\begin{array}{c}\text { Probabilit } \\
\text { y \% }\end{array}$ \\
\hline PROBI & 1 & 250.000 & 650 & 2 & 1.852 & .148 & 0.3 \\
\hline T After & 2 & 450.000 & 650 & 2 & 2.302 & $-.302-$ & 0.4 \\
\hline $5 \min$ & 3 & 650.000 & 650 & 3 & 2.846 & .154 & 0.4 \\
\hline PROBI & 1 & 250.000 & 650 & 3 & 3.359 & -.359 & 0.5 \\
\hline T After & 2 & 450.000 & 650 & 5 & 4.264 & .736 & 0.7 \\
\hline $10 \mathrm{~min}$ & 3 & 650.000 & 650 & 5 & 5.378 & $-.378-$ & 0.8 \\
\hline PROBI & 1 & 250.000 & 650 & 5 & 5.211 & $-.211-$ & 0.8 \\
\hline T After & 2 & 450.000 & 650 & 7 & 6.567 & .433 & 0.1 \\
\hline $15 \mathrm{~min}$ & 3 & 650.000 & 650 & 8 & 8.222 & $-.222-$ & 1.3 \\
\hline PROBI & 1 & 250.000 & 650 & 5 & 5.721 & $-.721-$ & 0.9 \\
\hline T After & 2 & 450.000 & 650 & 9 & 7.511 & 1.489 & 1.2 \\
\hline $20 \mathrm{~min}$ & 3 & 650.000 & 650 & 9 & 9.769 & -.769 & 1.5 \\
\hline PROBI & 1 & 250.000 & 650 & 5 & 5.721 & $-.721-$ & 0.9 \\
\hline T After & 2 & 450.000 & 650 & 9 & 7.511 & 1.489 & 1.2 \\
\hline $25 \mathrm{~min}$ & 3 & 650.000 & 650 & 9 & 9.769 & -.769 & 1.5 \\
\hline PROBI & 1 & 250.000 & 650 & 5 & 5.721 & $-.721-$ & 0.9 \\
\hline T After & 2 & 450.000 & 650 & 9 & 7.511 & 1.489 & 1.2 \\
\hline $30 \mathrm{~min}$ & 3 & 650.000 & 650 & 9 & 9.769 & -.769 & 1.5 \\
\hline
\end{tabular}

1- Laboratory experimental:

Results in Table 5 shows the concentration of volatile oil extract of Eucalyptus leaves needed to kill half of the total number of $A$. sardeus within time intervals $(5,10,15,20,25,30)$ minutes during laboratory experimental conditions; we note that when exposure periods are short in time, very high concentrations of the extract may be used up to
$1,497,696 \mathrm{ppm}$ to kill half of the whole number of A. sardeus in laboratory conditions. Therefore, we recommend increasing the exposure period when using appropriate concentrations that do not affect fish larvae. Even if such a high concentration of the extract is adopted, it can be seen that the degree of its effect on fish larvae is low (Table $6,4)$. 
Table 5. LC50 values of Eucalyptus sp. essential oil for $(5,10,15,20,25,30 \mathrm{~min}$.) exposure on A.sardea

\begin{tabular}{|c|c|c|c|c|c|}
\hline \multicolumn{6}{|c|}{ Confidence Limits } \\
\hline & \multirow{2}{*}{ Time (min.) } & & \multicolumn{3}{|c|}{ 95\% Confidence Limits for con (Ppm) } \\
\hline & & & Estimate & Lower Bound & Upper Bound \\
\hline \multirow{6}{*}{ PROBIT } & 5 & Probability & $1,497,696$ & 898.708 & 3175.387 \\
\hline & 10 & \multirow{5}{*}{$\mathbf{5 0 \%}$} & 757,303 & 632.359 & 1922.568 \\
\hline & 15 & & 472,492 & 190.127 & 788.257 \\
\hline & 20 & & 237,084 & 1932.621 & 64.751 \\
\hline & 25 & & 119,280 & 5923.748 & 667.179 \\
\hline & 30 & & - & - & - \\
\hline
\end{tabular}

the concentration of volatile oil extract needed to kill half of the fish larvae within the time periods of exposure $(5,10,15,20,25,30)$ minutes during field experiment conditions (Table 6), as can be seen that in all periods of short or long exposure time, very high concentrations of the extract may reach more than $6,000,000 \mathrm{ppm}$ to kill half of the fish larvae in the experimental conditions. This statistically proves that the use of this prepared Natural pesticide does not pose a threat to the organisms under the water surface. Therefore, even high concentrations of the extract are highly safe in field conditions on fish larvae.

Table 6. LC50 values of Eucalyptus sp. essential oil for $(5,10,15,20,25,30 \mathrm{~min}$.) exposure on fish larvae.

\begin{tabular}{|c|c|c|c|c|c|}
\hline \multicolumn{6}{|c|}{ Confidence Limits } \\
\hline & \multirow{2}{*}{ Time (min.) } & & \multicolumn{3}{|c|}{ 95\% Confidence Limits for con (ppm) } \\
\hline \multirow{7}{*}{ PROBIT } & & & Estimate & Lower Bound & Upper Bound \\
\hline & 5 & Probability & $4,655,363$ & 3331.122 & 19943.343 \\
\hline & 10 & & $4,573,082$ & 3196.528 & 19021.098 \\
\hline & 15 & & $5,287,805$ & 3086.953 & 18277.566 \\
\hline & 20 & $50 \%$ & $4,616,057$ & 3055.758 & 18061.957 \\
\hline & 25 & & $5,813,944$ & 3003.337 & 17710.930 \\
\hline & 30 & & $6,009,829$ & 2967.985 & 17471.382 \\
\hline
\end{tabular}

\section{2- Field experimental}

It is show from Table 7 that suitable concentrations can be used (within the limits

of the concentrations used in this experiment $250,000,450,000$ and 650,000 . If exposure periods are used within longer periods of time (more than 10 minutes),

Table 7. LC50 values of Eucalyptus sp. essential oil for $(5,10,15,20,25,30 \mathrm{~min}$.) exposure on

A. sardea

\begin{tabular}{|c|c|c|c|c|c|}
\hline \multicolumn{6}{|c|}{ Confidence Limits } \\
\hline & \multirow{2}{*}{ Time (min.) } & \multirow{2}{*}{ Probability } & \multicolumn{3}{|c|}{ 95\% Confidence Limits for con (ppm) } \\
\hline \multirow{7}{*}{ PROBIT } & & & Estimate & Lower Bound & Upper Bound \\
\hline & 5 & \multirow{6}{*}{$50 \%$} & 2,392,027 & 1177.993 & 5842.509 \\
\hline & 10 & & $2,165,455$ & 871.636 & 3875.331 \\
\hline & 15 & & 648,457 & 402.641 & 1577.523 \\
\hline & 20 & & 539,270 & 226.023 & 1151.729 \\
\hline & 25 & & 423,527 & 38.956 & 819.601 \\
\hline & 30 & & 250,765 & 678.043 & 497.683 \\
\hline
\end{tabular}

concentrations from the extract that may be close to $250,000 \mathrm{ppm}$ ) may be used to kill half the total number of the aquatic insect $A$. sardeus in the field experimental conditions during a period of exposure (30) minutes to ensure that the fish larvae do not affect, i.e., the greater the exposure period the less concentration of extract used in the field experiment. It is clear from Table 8 (as in the laboratory experiment) that in all periods of short-term or long-term exposure should use very high concentrations of the extract may 
reach more than $7,973,526 \mathrm{ppm}$ to kill half of the number of fish larvae in the experimental conditions, which shows the lack of toxicity on fish larvae,the fact that this oil in the spread on the surface of the water has almost no effect

Table 8. LC50 values of Eucalyptus sp. essential oil for $(5,10,15,20,25,30 \mathrm{~min}$.) exposure on fish larvae

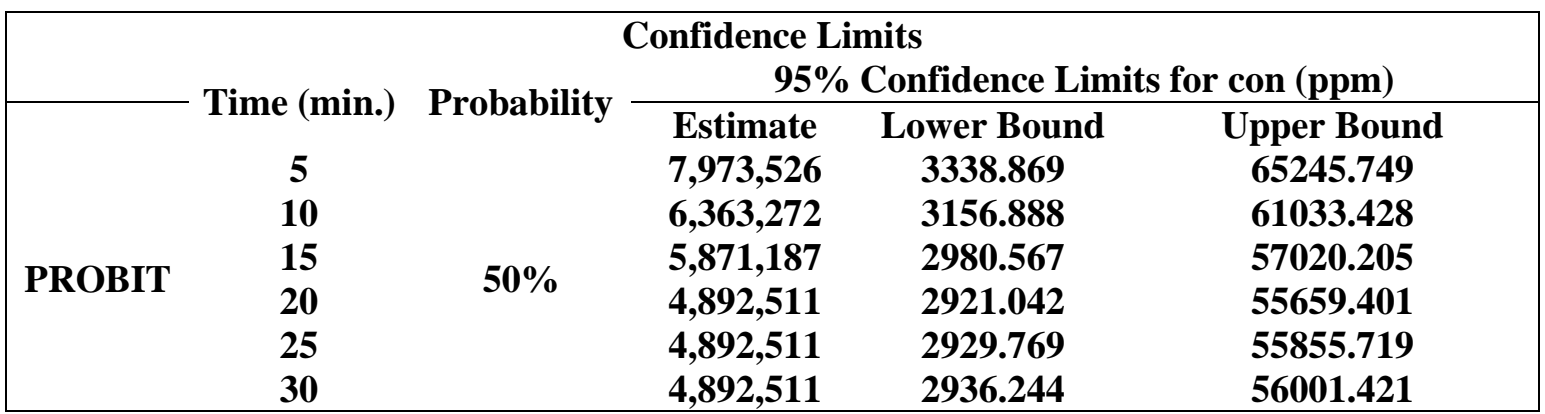

The correlation between the concentration of the volatile oil extract of the Eucalyptus leaves and the response of both aquatic insects $A$. sardeus, and fish larvae within time periods (5, $10,15,20,25,30)$ can be estimated by curves in Figures (1-4) where the correlation coefficient value ( R2) this relationship, the value of $(\mathrm{X})$ represents one toxic lethal unit, which increases by one unit, the rate of killing increases with different values. From curves in Figure 1 as the concentration of the extract increases by one part per million, the killing rate of $A$. sardeus is increased by $\left(9.48 * 10^{4}\right)$ $\%$ in exposure period (15) minutes, it is the highest among the rest of the exposure in the laboratory experiment note that the program did not draw this relationship in periods of exposure $(25,30)$ minutes because the killing rates reached $100 \%$. Curves in Figure 2 show that the greater the concentration of the extract one part per million increase the killing rate of fish larvae by $\left(5.54 * 10^{4)} \%\right.$ in the exposure period (5) minutes, which is the highest among the rest of the exposure periods in the laboratory experiment. While in Figure 3 the higher the concentration of the extract, one part per million, the percentage of killing $A$. sardeus total increases by $\left(9.78 * 10^{4}\right) \%$ in the exposure period (15) minutes, which is the highest among the rest of the exposure in the field experiment and followed by slightly less $\left(9.53 * 10^{4}\right) \%$ in Exposure period (20) minutes. Curves in figure (4) show that the greater the on these larvae, and because of the high volatility of the extract, so the use of even high concentrations of the extract is very safe in the field conditions on fish larvae concentration of the extract one part per million increase the killing rate of fish larvae by $\left(5.54 * 10^{4}\right) \%$ in the last three periods of exposure $(20,25,30)$ minutes, which is the highest among the rest of the exposure in the field experiment.

\section{3- Gas Chromatography Analysis:}

The result of Gas Chromatography to the Eucalyptus sp. essential volatile oil showed presence of (Sabinen 0.06, Terpinen 2.0, Lemonine 1.08, Camphene 3.45, $\alpha$-pinene 10.0, Myrcine 0.62, Comphore 2.9, Linalool $0.027) \%$ according to the slandered curves While an analysis was performed by Mustafa, (32) on (100g) of dried Eucalyptus Camaldulensis leaves showed the presence of compounds ( $\alpha$-pinene 4.68, 4-Terpineol 4.22, Myrtenal 2.46, $\alpha$-Terpinolene 1.96, $\alpha-$ Terpineol 1.79, Trans-Pinocarveol 1.68, $\alpha$ Thujene 1.33, Bicyclogirmacrene 0.84, Myrcene 0.65 , Terpinene 0.53)\%with percentage respectively. The eucalyptus spp. oil is a combination of a variety of monoterpenes and sesquiterpenes, and aromatic phenols, oxides, ethers, alcohols, esters, aldehydes and ketones. The pesticidal activity of eucalyptus oils has been due to the components such as 1,8-cineole, citronellal, citronellol, citronellylacetate, p-cymene, eucamalol, limonene, linalool, a-pinene, $\mathrm{g}$ terpinene, a-terpineol, alloocimene, and aromadendrene $(6,7,12,15,24,25,28,42)$. 


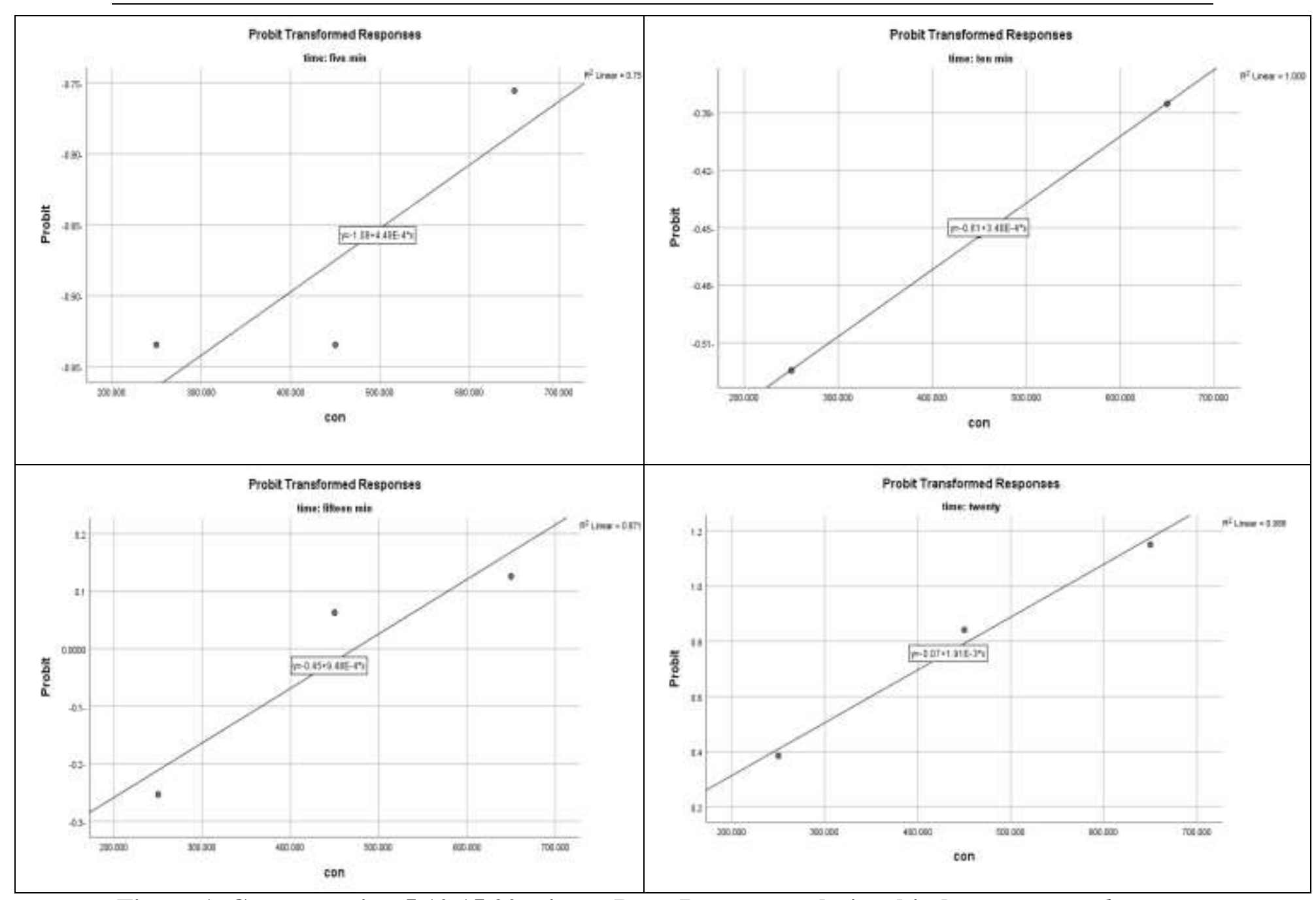

Figure 1. Concentration 5,10,15,20 minute Dose-Response relationship between Eucalyptus sp. leaves essential oil and for $A$. sardeus in laboratory experimental 
Ali \& et al.

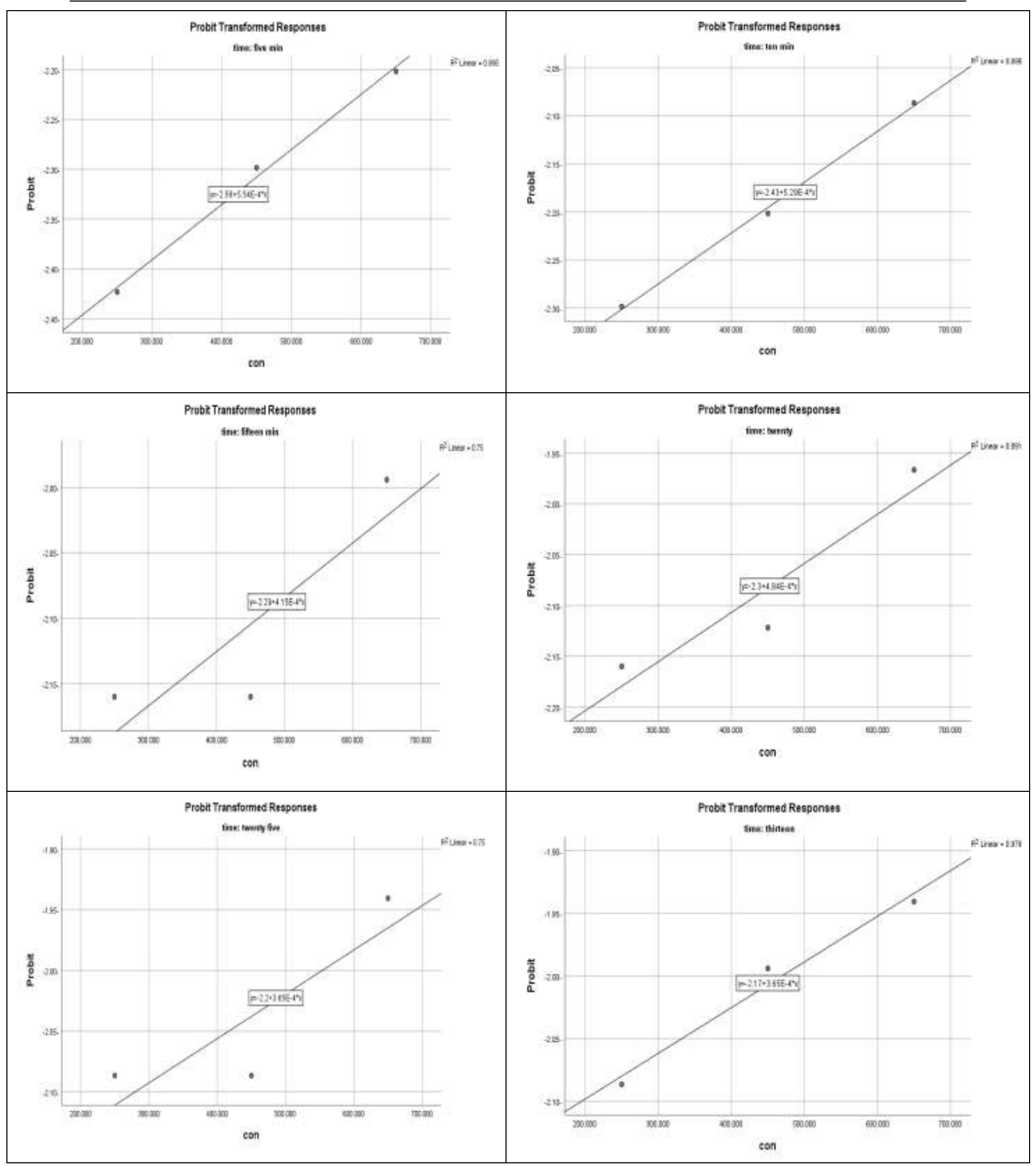

Figure 2. Concentration 5, 10, 15,20,25,30 minute Dose-Response relationship between Eucalyptus sp. Leaves essential oil and for fish larvae in laboratory experimental 
Ali \& et al.

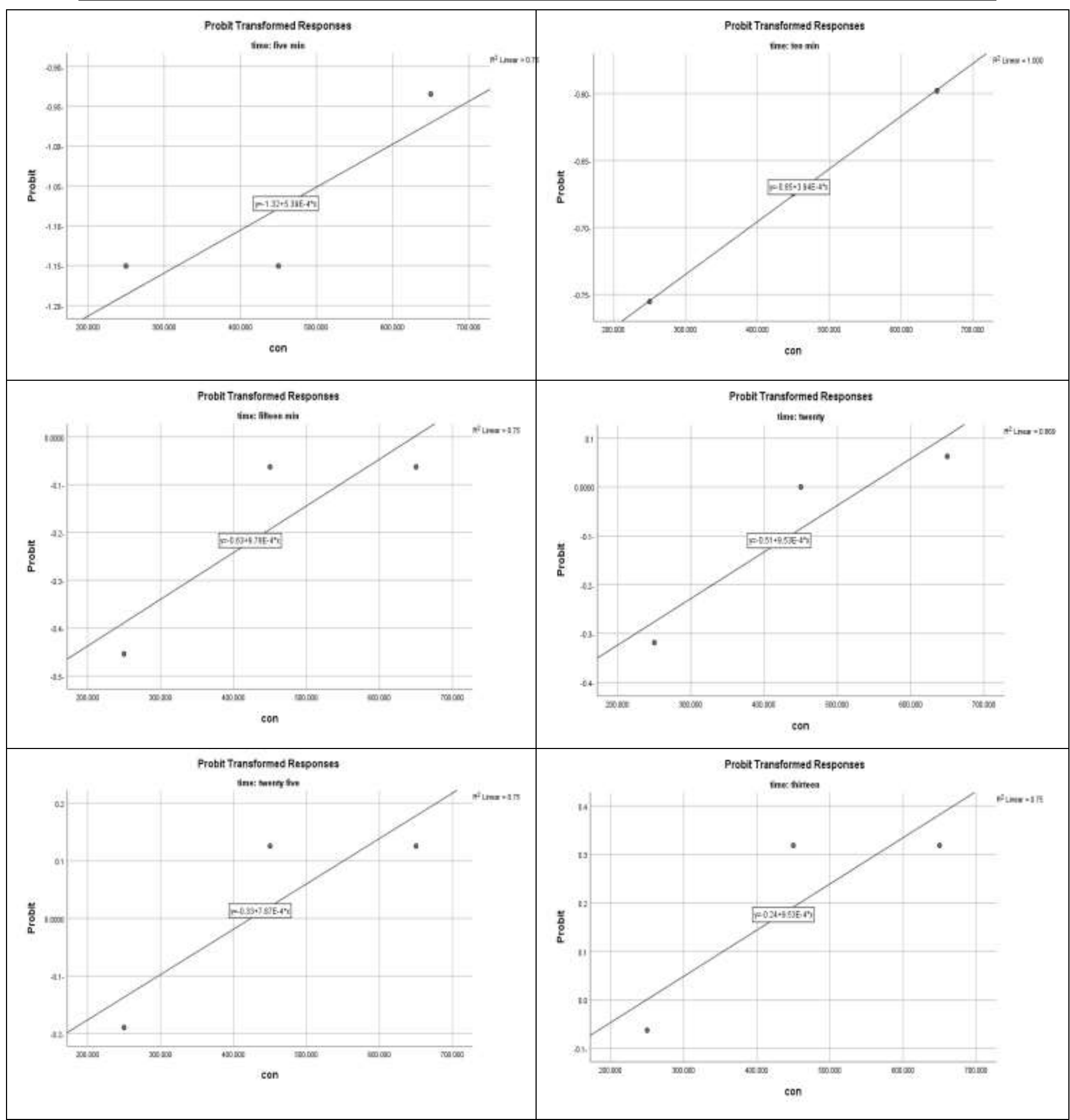

Figure 3. Concentration 5, 10, 15, 20, 25, 30 minute Dose-Response relationship between Eucalyptus sp. leaves essential oil and for A. sardeus in field experimental 


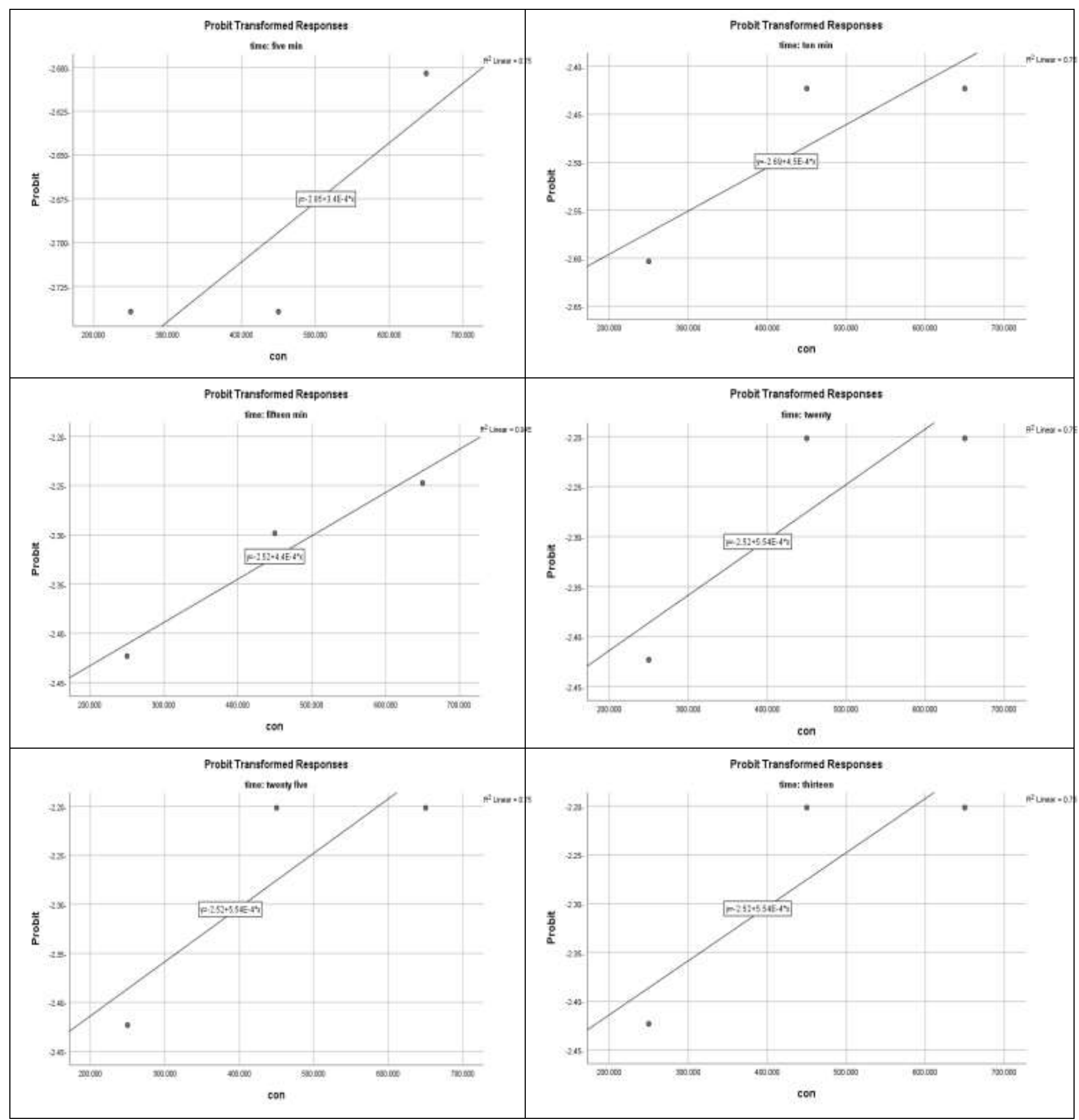

Figure 4. Concentration 5,10,15,20,25,30 minute Dose-Response relationship between Eucalyptus sp. leaves essential oil and for fish larvae in Field experimental

\section{REFERENCES}

1. Agarwal R, M.D Kharya, R. Shrivastava 1979. Antimicrobial and anthelmintic activities of the essential oil of Nigella sativa L. Indian J Exp Biol, 17: 1264-1265

2. Al-Salami, W.M. 1998. Effect of Plant Extract of Convolvulus Arvensis L and Hindal Herb Ipomoea Caririca (Linn.) in The Bio-
Performance of Grain-Wheat Aphid Schizaphis graminum (Homoptera: Aphididae). Ph. D Dissertation, College of Science, University of Babylon, pp:111 (in Arabic).

3. Aukema B., C. Rieger and W. Rabitsch 2013. Catalogue of the Heteroptera of the Palaearctic Region. VI. Supplement. The 
Netherlands Entomological Society,

Amsterdam, xxiii + pp: 629

4. Barry M.J. 1997. Effects of food limitation, notonectid predation, and temperature on the population dynamics of Daphnia carinata. Int. Rev. Hydrobiol. 82: 545-562

5. Batish, D.R., N. Setia, H.P Singh and R.K. Kohli 2004. Phytotoxicity of lemon-scented eucalypt oil and its potential use as a bioherbicide. Crop Prot. 23, 1209-1214

6. Batish, D. R., H.P. Singh, R.K. Kohli and S. Kaur 2008. Eucalyptus essential oil as a natural pesticide.Forest Ecology and Management (256): 2166-2174

7. Batish, D.R., H.P. Singh, N Setia, S. Kaur and R.K Kohli 2006. Chemical composition and phytotoxicity of volatile essential oils from intact and fallen leaves of Eucalyptus citriodora. Z. Naturforsch. c61, 465-471

8. Berchi G.M. 2011. First record of Anisops sardeus (Hemiptera: Heteroptera: Notonectidae) in Romania. North-West. J. Zool. 7: 339-341

9. Brooker, M.I.H. and D.A. Kleinig, 2006. Field Guide to Eucalyptus. vol. 1. Southeastern Australia, $3^{\text {rd }}$ ed. Bloomings, Melbourne, pp: 132

10. Brooks, G.T. 1951. A revision of the genus Anisops (Notonectidae: Hemiptera). Univ. Kansas Sci. Bull., 34: 301-519

11. Cianferoni, F. and A. Pinna 2012. Segnalazioni faunistiche italiane, 529: Anisops sardeus sardeus Herrich-Schäffer, 1849 (Hemiptera, Heteroptera, Notonectidae), Boll. Soc. Entomol. Ital., 144(1): 44-48

12. Cimanga, K., K. Kambu, L. Tona, S. Apers, T. De Bruyne, N. Hermans, J. Totte, L. Pieters, and A.J Vlietinck 2002. Correlation between chemical composition and antibacterial activity of essential oils of some aromatic medicinal plants growing in the Democratic Republic of Congo. J. Ethnopharm. 79, 213-220

13. Cooper S.D. 1983: Selective predation on cladocerans by common pond insects. Can. J. Zool. 61: 879-886

14. Dayan, F.E., C.L Cantrell and S.O. Duke 2009. Natural products in crop protection. Bioorganic and Medicinal Chemistry 17: 4022-4034.

15. Duke, J.A., 2004. Dr. Duke's Phytochemical and Ethnobotanical databases.
Available online at http://www.arsgrin.gov/duke/

16. Eitam A, L Blaustein and M. Mangel 2002 Effects of. Anisops sardea (Hemiptera: Notonectidae) on oviposition habitat selection by mosquitoes and other dipterans and on community structure in artificial pools. Hydrobiologia 485 : 183-9

17. Fent, M., P. Kment, B. Çamur and T. ElipekKirgiz, 2011. Annotated catalogue of Enicocephalomorpha,

Gerromorpha and Leptopodomorpha (Hemiptera: Heteroptera) of Turkey, with new records. Zootaxa 2856: 1-84

18. Getahun, Y. W. and S. Welderufael, 2016. Natural pesticide from Eucalyptus camaldulensis essential oil and its synergetic effect with eucalyptus globulus essential oils. Journal of Natural Sciences Research, 6(3).:122-131

19. Giller P.S. 1986. The natural diet of the Notonectidae: field trials using electrophoresis. Ecol. Entomol. 11: 163-172

20. Katbeh, A., A.Carapezza and M. Akkawi 2000. Heteroptera of Jordan: Specimens preserved in the University of Jordan Insects Museum (Insecta).

Attidell'AccademiaRoveretanadegliAgiati,

SeriaVII (10B): 111-137

21. Klementová, B. R. and M. Svitok 2014. Anisopssardeus (Heteroptera): A new expansive species in Central Europe, Biologia 69(5): 676-680

22. Kment, P. and L. Beran, 2011 Check-list of water bugs (Hemiptera: Heteroptera: Nepomorpha) in Croatia with two new records and four rediscoveries. Natura Croatica 20(1): 159-178

23. Lahr, J., A.O. Diallo, K.B. Ndour, A. Badji and P.S. Diouf 1999. Phenology of invertebrates living in a sahelian temporary pond. Hydrobiologia 405: 189-205

24. Li, H., J.L. Madden and B.M. Potts, 1995. Variation in volatile leaf oils of the Tasmanian Eucalyptus species-1. Subgenus Monocalyptus. Biochem. Syst. Ecol. 23, 299318

25. Li, H., Madden, J.L., Potts, B.M., 1996. Variation in volatile leaf oils of the Tasmanian Eucalyptus species II. Subgenus Symphyomyrtus. Biochem. Syst. Ecol. 24, 547-569 
26. Lindholm $M$ and D.O Hessen 2007 Competition and niche partitioning. in a floodplain ecosystem: a cladoceran community squeezed between fish and invertebrate predation. Afr Zool $4: 158-64$

27. Linnavuori, R. 1964. Hemiptera of Egypt, with remarks on some species of the adjacent Eremian region. Annales Zoologice Fennici 7: 306-356

28. Linnavuori, R.E. and R. Hosseini, 2000. Heteroptera of Guilan with Remarks on Species of the Adjacent Areas. Part 1. Guilan University Publication, Rasht. pp: 143

29. Liu, X., Chen, Q., Wang, Z., Xie, L., Xu, Z., 2008. Allelopathic effects of essential oil from Eucalyptus grandis _ E. urophylla on pathogenic fungi and pest insects. Front. Forestry China 3, 232-236

30. Maciel, M.V., S.M. Morais, C.M., Bevilaqua, R. A Silva, R. S. Barros, R. N. Sousa, L.C. Sousa, E.S. Brito and M.A. Souza 2010. Chemical composition of Eucalyptus spp. essential oils and their insecticidal effects on Lutzomyia longipalpis. Veterinary Parasitology, 167, 1-7

31. Mondal, R. P., A. Ghosh, S. Bandyopadhyay and G. Chandra 2014. Functional response analysis ofAnisops sardea (Hemiptera: Notonectidae) against Culex quinquefasciatus in laboratory condition, Indian J Med Res 140: 551-555

32. Mustafa, M. AG. 2019. Effect of Eucalyptus leaves and its supplementation with diet on broiler performance, microbial and physiological statues to alleviate cold stress. Iraqi Journal of Agricultural Sciences, 50 (1): 953-963

33. Polhemus J.T. 1996. Notonectidae, pp 63 73. In: Aukema B. and C .Rieger (eds), Catalogue of the Heteroptera of the Palaearctic Region. Vol. 1, The Netherlands Entomological Society, Amsterdam, pp: 222

34. Protić, L. 1998. Catalogue of the Heteroptera Fauna of Yugoslav Countries. Part one. PrirodnjačkiMuzej u Beogradu, PosebnaIzdanja pp: 38

35. Sarwar, M. and M. Sattar, 2012. Appraisal of different plant products against
Trogodermagranarium everts to protect stored Wheat- A laboratory comparison. Nucleus, 49 (1): $65-69$

36. Sarwar, M., A. Ali, N. Ahmad, and M. Tofique, 2005. Expediency of different botanical products intended for managing the population of rice stem borers. Proce. $25^{\text {th }}$ Pakistan Conger of Zoology, March 1-3, Sindh Agriculture University, Tandojam, 25: 15-23 . 37. Sarwar, M., M. Ashfaq, A. Ahmad and M.A.M. Randhawa 2013. Assessing the potential of assorted plant powders on survival of Caloglyphus grain mite (Acari: Acaridae) in wheat grain. International Journal of Agricultural Science and Bioresource Engineering Research, 2 (1): 1-6

38. Shaaya, E., U. Ravid, N. Paster, B. Juven, U. Zisman and V. Pissarev 1991. Fumigant toxicity of essential oils against four major stored-product insects. J. Chem. Ecol., 17: 499-504

39. Shapovalov, M. I. and M. A. Saprykin, 2018. New record of water bug Anisops sardeus Herrich-Schaeffer, 1849 (Heteroptera, Notonectidae) in water basins of southern russia. Russian Journal of Biological Invasions, 9(3): 286-289.

40. Soos N., A. Petri, Z. Nagy-Laszlo and Z. Csabai 2010. Anisops sardeus HerrichSchaeffer, 1849: first records from Hungary (Heteroptera: Notonectidae). Folia Entomol. Hung. 71: 15-18

41. Sridharan S, V. Balasubramani S. Jeyarani and S. Sadakathulla 2000. Aquatic hemipteran predators in rice ecosystem. Insect Environ 5: 189-90

42. Su, Y.C., C.L. Ho, I.C. Wang and S.T. Chang 2006. Antifungal activities and chemical compositions of essential oils from leaves of four eucalypts. Taiwan J. For. Sci. 21, 49-61

43. Tawfik MFS, MM El-Husseini and $\mathrm{H}$. Abou Bakr 1986. The biology of the notonectid Anisops sardea H. S., an active mosquito predator in Egypt. Bull. Entomol.Soc. Egypt., 66: 117-26. 